\title{
Molecular Characterization of Genetic Variability among Sudanese Baggara Cattle within Kappa Casein CSN3 Gene (Exon V)
}

\section{Huiam $M E^{1}$, Eltahir $S^{2}$ and Hamza $\mathrm{AE}^{2 *}$}

${ }^{1}$ Ministry of Animal Resources, South Darfur State, Sudan

${ }^{2}$ Institute of Molecular Biology (IMB) University of Nyala, Sudan

*Corresponding author: Hamza AE, Institute of Molecular Biology (IMB), University of Nyala, Nyala, Sudan, Tel: 249711833122; E-mail: waderabie@gmail.com

Received date: November 21, 2017; Accepted date: November 23, 2017; Published date: December 01, 2017

Copyright: () 2018 Huiam ME, et al. This is an open-access article distributed under the terms of the Creative Commons Attribution License, which permits unrestricted use, distribution, and reproduction in any medium, provided the original author and source are credited.

\begin{abstract}
The present work was conducted to detect possible genetic variants of kappa casein (CSN3) gene in Western Baggara cattle in Sudan. This gene is associated with higher fat, protein, and has a significant influence on milk processing properties in comparison to other casein variants.70 blood samples were collected from Western Baggara cattle in three areas (Hai Elgabal, Bulbul and Umdamm). Genomic DNA was extracted from the whole blood using guanidine chloroform method. A $495 \mathrm{bp}$ fragment containing exon $\mathrm{V}$ of kappa casein gene was amplified by PCR using specific set of primers. The amplified PCR product was digested by Hinf1; the bands were visualized under UV-light to observe the polymorphic locus by the size change of DNA fragments. The results revealed that the restriction analysis produced two fragments of 424 and $71 \mathrm{bp}$ indicating the presence of kappa casein BB genotype (monomorphic) in all population. The present study is the first report on kappa casein genotype of Baggara cattle in South Darfur State, Sudan, which elucidated uniform and homozygous population for kappa casein B allele.
\end{abstract}

Keywords: Molecular characterization; CSN3; Exon4; Baggara cattle; Sudan

\section{Introduction}

Milk is very important in human nutrition because, it provides energy, high quality protein, vitamins and minerals requirements. However, among the different composition milk protein is considered the most important component therefore, investigation on milk protein particularly caseins is still arousing research interest due to their crucial role in milk quality, composition and processing properties [1].

Out of fourteen variants of $\kappa-\mathrm{CN}$ have been explained i.e. A, A1, B, B2, C, D, E, F1, F2, G1, G2, H, I and J; the A and B are most common in the majority of cattle breeds followed by $\kappa-\mathrm{CNs} \mathrm{H}$ [2]. The majority of researchers believe that the kappa casein $\mathrm{B}$ variant is associated with higher fat, protein, and casein in the milk and has a significant influence on cheese making properties of milk and superior rennet coagulation properties in comparison to $\mathrm{AA}$ or $\mathrm{AB}$ variants. The genotypes $\mathrm{BB}$ and $\mathrm{AB}$ are used in artificial insemination programs to obtain a greater increase of the frequency of these alleles in cattle populations of commercial interest [3].

Western Baggara cattle is belonging to Northern Sudan zebu cattle which represent $(33 \%)$ of the national herd of the Sudan and contribute effectively in Sudan Gross Domestic Product (GDP) and providing meat source for both export and local consumption and also playing a vital role in improving the livelihoods and enhancing the food security for nomadic tribes in their natural habitat in Kordofan and Darfur [4].

The classifications of Sudanese cattle are based on phenotypic characteristics or geographic origin and are not related to genotype except in as much as the phenotype is in part a reflection of genotype. With the advent of molecular biology technology, a powerful new tool is available for characterization, classification and estimation of distances between breeds and strains. The investigation of genetic variation is very important for future monitoring of gene flow in populations, conservation of species, determination of the level of inbreeding and crossbreeding within and between breeds [5]. The present work was prepared as first attempt to detect possible genetic polymorphism within CSN3 gene (exon four) of Baggara cattle in South Darfur state, Sudan.

\section{Materials and Methods}

\section{Collection of blood samples}

Blood samples were obtained from the jugular veins of 70 Western Baggara cows in areas of the study (Bulbul, Hai Elgabal, and Umdamm). $10 \mathrm{~mL}$ were taken from each cow from the jugular vein in a clean sterile tube contains EDTA and stored at $-20^{\circ} \mathrm{C}$ until time of DNA extraction.

\section{DNA extraction}

Genomic DNA was extracted from the whole blood using guanidine chloroform method as described by Ciulla et al. [6]. Quality and concentration of the DNA was checked by electrophoresis on $2 \%$ Agarose gel.

\section{PCR amplification}

A 495 bp fragment containing exon $\mathrm{V}$ of kappa casein gene was amplified by PCR using forward 5'GGATTCTCCAGGCAAGAAATAA3' and reverses 5 GTGGGCTCTCAATAACTTCTG 3', PCR was carried into $20 \mu \mathrm{L}$ volume of PCR amplification cocktail contained $1 \mu \mathrm{L}$ of each primer, $1 \mathrm{x}$ PCR master mix (DYNAzyme), $2 \mu \mathrm{l}$ of template DNA and $16 \mu \mathrm{L}$ of double distilled water. The amplification cycles were carried out in a 
Citation: Huiam ME, Eltahir SS, Hamza AE (2018) Molecular Characterization of Genetic Variability among Sudanese Baggara Cattle within Kappa Casein CSN3 Gene (Exon V). Mol Biol 7: 198. doi:10.4172/2168-9547.1000198

Page 2 of 3

PTC-100 thermocycler. Reaction conditions were $94^{\circ} \mathrm{C}$ for $5 \mathrm{~min}$ as initial denaturation followed, by 30 cycles of $94^{\circ} \mathrm{C}$ for $1 \mathrm{~min}, 58^{\circ} \mathrm{C}$ for 1 min and $72^{\circ} \mathrm{C}$ for $1 \mathrm{~min}$. a final extension step at $72^{\circ} \mathrm{C}$ for 5 min was followed.

\section{Restriction fragment length polymorphism (RFLP)}

After PCR the product was digested by 7.5 units of haemophilus influenza serotype $\mathrm{F}$ restriction enzyme (Hinf1) in a final volume of 25 $\mu \mathrm{L}$ containing $1 \mathrm{x}$ of the enzyme buffer $(2.5 \mu \mathrm{L}), 5 \mu \mathrm{L}$ of PCR product and 17 double distilled water. The digestion mixtures were incubated at $37^{\circ} \mathrm{C}$ overnight in the incubator. After digestion, the resulting fragments were analyzed by electrophoresis on $2 \%$ agarose gel using $1 \mathrm{x}$ TBE buffer containing $0.2 \mu \mathrm{L}$ ethidum bromide at $50 \mathrm{~V}$ until complete separation of the bands. The bands were visualized under UV-light to observe the polymorphic locus by the size change of DNA fragments.

\section{Results}

Restriction Fragment Length Polymorphism (RFLP) said to be one of the most accurate, low cost and reliable technique for the identification of structural gene polymorphism that occur as a result of point mutation [2]. In this work; PCR was used for gene amplification using specific primers yielded a 495 bp fragment of kappa casein gene. Observation of a single band visible under UV light removed the need for PCR purification step before restriction analysis as shown in Figure 1 .

RFLP analysis was used for allele typing. Genotyping was performed by the restriction digestion of the amplified products using Hinf1 restriction enzyme followed by agarose gel electrophoresis for analysis of the digestion pattern and the restriction analysis produced two fragments of 424 and $71 \mathrm{bp}$ indicating the presence of kappa casein BB genotype (monomorphic) in all population (Figure 2).

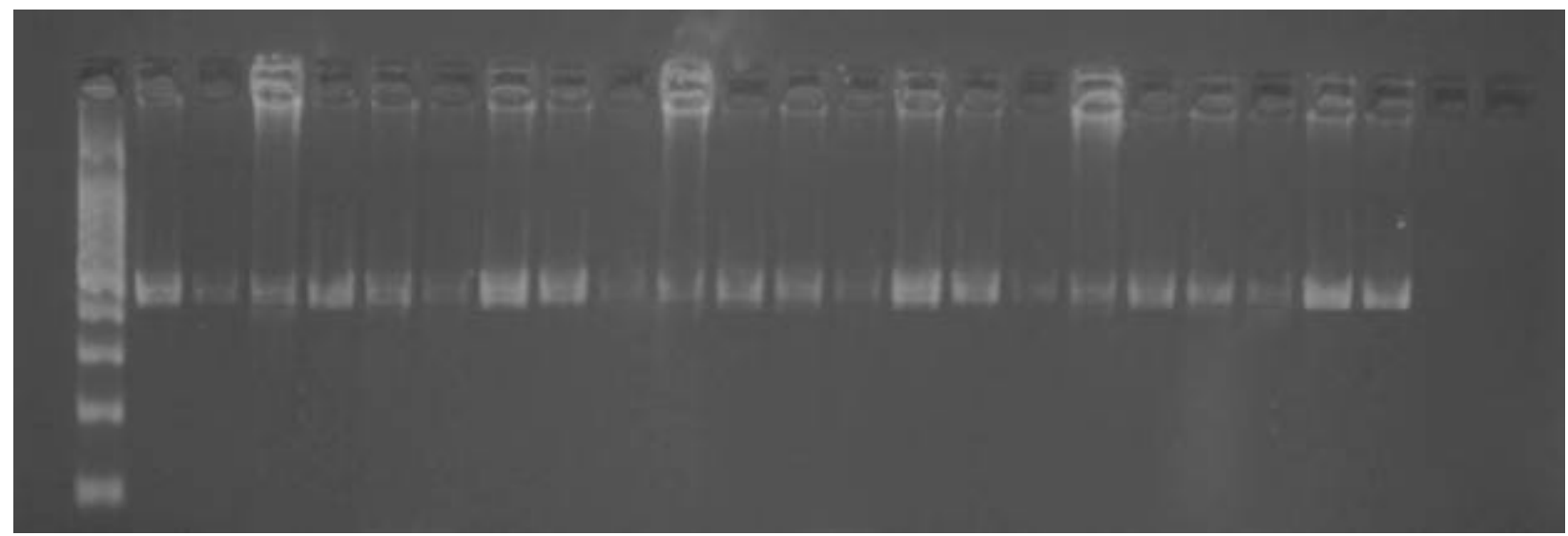

Figure 1: The amplification of cattle kappa casein gene exon 4 .

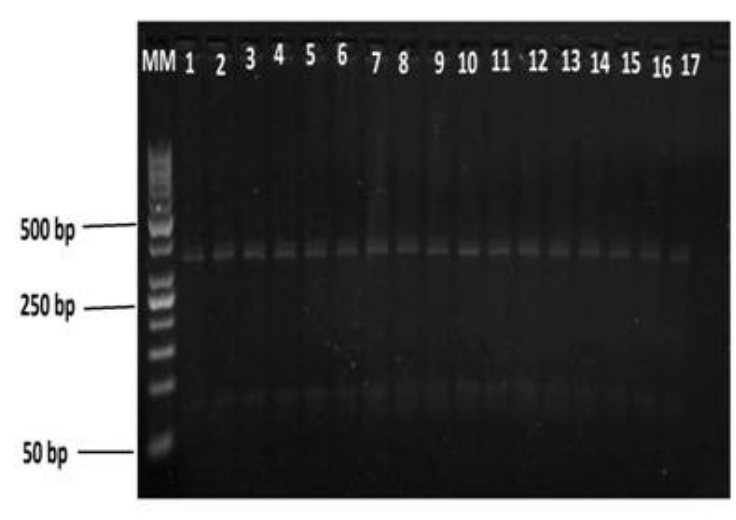

Figure 2: RFLP product of kappa casein gene after digested by Hinf1 showed two fragments (424 and $71 \mathrm{bp}$ ) represented homozygous B allele.

\section{Discussion}

The present study was aimed to detect possible kappa casein gene polymorphism within exon four among Western Baggara cattle breed. PCR-RFLP technique was used to detect kappa casein genetic variants. A 495 bp fragment of kappa casein gene was digested by Hinf1 restriction enzyme. The results indicated that all studied population of Baggara cattle was found to be monomorphic genotype (BB) with only two bands (71 and $424 \mathrm{bp}$ ). The results in the present study were in agreement with numerous researchers: Riaa et al. [7] who detected one allele (BB) in Nilli Rvi breed of Pakistan and Raj et al. [8] and El Rafey and Darwish [9] detected the gene in Egyptian buffalo, Osman [10] reported one allele $\mathrm{BB}$ genotype among River Buffalo breed and also, reported monomorphic (BB) for this gene in female buffaloes. Similarly, Zakizaden et al. [11] reported that the frequency of B allele of kappa casein gene in Holstein breed ranges from (0.06-0.57). Some researchers observed highest frequency of allele (B) in Brown Swiss and Jersey with 0.67 and 0.86 , respectively [12-16], however, frequency of this allele (B) in Norwegian cattle breeds and Northern region of Europe was found low [17,18]. Also, Faradi et al. [19] reported genotype $\mathrm{AA}, \mathrm{AB}$ and $\mathrm{BB}$ with frequencies of $35 \%, 37.5 \%$ and $27 \%$, respectively among Najdi cattle breed this indicated that $\mathrm{BB}$ homozygous frequency was low.

On the other hand, the present findings were not in line with Rahamtalla et al. [20] who studied polymorphism of kappa casein gene 
in Butana and Kenana dairy cattle and found frequencies of allele A was higher than allele B but, where, BB genotype was not observed [21]. Also, the present results were not agree with Memon et al. [2] who found the genotype frequency for homozygote AA and the allelic frequency of allele A were higher than the same for homozygote genotype $\mathrm{BB}$ and the allelic frequency of allele $\mathrm{B}$, respectively in Pakistani Sindhi cattle. Deb et al. [21] reported that the A allele was more frequent than the $\mathrm{B}$ allele and no BB homozygous was observed among the Frieswal (HF $\times$ Sahiwal) cross breed of Indian origin. Also, the present results were in disagreement with Mitra et al. [22] who observed low frequency of $\mathrm{B}$ allele and absence of homozygous $\mathrm{BB}$ animals in Sahiwal cattle. Ng-Kwai-Hang et al. [23] claimed that the frequency distribution of kappa casein genotypes shows rare occurrence in Holstein breeds.

\section{Conclusion}

The present study is the first report on kappa casein genotype of Baggara cattle in South Darfur State, Sudan, which indicated uniform and homozygous population for kappa casein B allele.

The majority of researchers believe that the kappa casein B variant is associated with higher fat, protein, and casein in the milk and has a significant influence on cheese making properties of milk and superior rennet coagulation properties in comparison to $\mathrm{AA}$ or $\mathrm{AB}$ variants, therefore, In future genetic improvement strategies; homozygous population of kappa casein B allele for western Baggara cattle should be considered.

\section{References}

1. Martin P, Brington G, Furet JP, Leroux C (1996) The gene encoding as1casein is expressed in human mammary epithelial cells during lactation. Lait 76: 526- 537.

2. Memon IA, Raza MA, Vistro WA, Leghari MF, Nizamani AW, et al. (2016) Marker assisted molecular investigation of kappa-casein gene in Bos indicus Sindhi genetic group using HINFI restriction enzyme. Int Arch BioMed Clin Res 2: 34-39.

3. Otaviano AR, Tonhati H, Sena JAD, Munoz MFC (2005) Kappa casein gene study with molecular markers in females buffalo. J Mol Biol 28: 237-241.

4. Bashir HHA, Elzubier IEM. (2013) Socio economic, husbandry and constrains of Baggara cattle under extensive and semi extensive system in South Kordofan State. Worlds Vet J 3: 11-16.

5. Kunene N, Nesamvuni EA, Fossey A (2007) Characterization of Zulu (Nguni) sheep using linear body measurements and some environmental factors affecting these measurements. J Anim Sci 37: 11-20.

6. Ciulla T, Sklar R, Hauser S (1988) A simple method for DNA purification from peripheral blood. Anal Biochem 174: 485-488.

7. Riaz MN, Malik NA, Nasreen F, Qureshi JA (2008) Molecular marker assisted study of kappa casein gene in Nilli-Ravi 9Buffalo) breed of Pakistan. Pak Vet J 28: 103-106.
8. Raj GD, Shetty S, Govindaiah MG, Nagaraj CS, Byregonds SM, et al. (2008) Molecular characterization of kappa casein gene in buffaloes. Sciencesia 34: 435-439.

9. El Rafey GA, Darwish SF (2007) A PCR RFLP assay to detect genetic variants of kappa casein gene in cattle and buffalo. J Arab Biotechnol 11: 11-18.

10. Osman EO (2005) The identification of kappa casein genotyping in Egyptian river buffalo using PCR- RFLP. Cell Biology Department, Genetic Engineering and Biotechnology Division. J Arab Biotechnol 8: 265-274.

11. Zakizaden S, Nejati JA, Reissmann M, Rahimi G, Jahan BA (2007) Analysis of selection effect based on kappa casein gene on milk yield production of Iranian Sarabi cattle using stochastic simulation. Pak J Biol Sci 10: 941-945.

12. Tsiaras AM, BargoUli GG, Banos G, Boscos CM (2005) Effect of $\kappa$ casein and Beta-lactoglobulin loci on milk production traits and reproductive performance of Holstein Cows. J Dairy Sci 88: 327-334.

13. Bobe G, Beitz DC, Freeman AE, Lindberg GL (1999) Effect of milk protein genotypes on milk protein composition and its genetic parameter estimates. J Dairy Sci 82: 2797-2804.

14. Ron M, Yoffe O, Ezra E, Meldrano JF (1994) Determination of effect milk protein genotype on production traits of Israeli Holsteins. J Dairy Sci 77: 1106-1113.

15. Cowan CM, Dentine MR, Ax RL, Schuler LA (1990). Structural variation around prolactin gene linked to quantitative traits in an elite Holstein sire family. Theor App Genet 79: 577-582.

16. Van EAL, Medrano JF (1991) Differences in allelic protein expression in the milk of heterozygous K-casein cows. J Dairy Sci 74: 1491-1496.

17. Pinder SJ, Perry BN, Skidmore CJ, Savva D (1991) Analysis of polymorphism in the bovine casein genes by use of the polymerase chain reaction. J Anim Genet 22:11-20.

18. FitzGerald RJ (1998) Potential uses of casein phosphor peptides. Int Dairy J 8: 451-457.

19. Faradi G, Beigi Nassiri MT, Fayazi J Roshanfekr H (2014) Investigation of kappa casein gene polymorphism by PCR RFLP in Najdi cattle breeds population in khuzestan province. Iran J Appl Anim Sci, 4: 281-284.

20. Rahamtalla SA, Reibmann M, Mueller U, Brockmann GA (2015) Identification of genetic variants influencing milk production traits in Sudanese dairy cattle. J Anim Res Sci 9: 12-22.

21. Deb R, Singh U, Kumar S, Singh R, Sengar G, et al. (2014) Genetic polymorphism and association of kappa-casein gene with milk production traits among Frieswal $(\mathrm{HF} \times$ Sahiwal) cross breed of Indian origin. IJVR 15: 406-408

22. Mitra AP, Schlee I, Krause J, Blusch T, Werne CR, et al. (1998) Kappa casein Polymorphism in Indian dairy cattle and Buffalo: A new genetic variant in Buffalo. Anim Biotechnol 9: 81-87.

23. Ng-Kwai-Hang KF, Monardes HG, Hayes JF (1990) Association between genetic polymorphism of milk proteins and production traits during three lactations. J Dairy Sci 73: 3414-3420. 